\title{
Transfusion in the New Millennium
}

\author{
Ennio C. Rossi ${ }^{1}$ \& Toby L. Simon ${ }^{2}$ \\ ${ }^{1}$ Professor Emeritus of Medicine, Northwestern University School of Medicine, Chicago, Illinois, USA \\ ${ }^{2}$ Corporate Medical Director, ZLB Plasma, a CSL Behring Company, Boca Raton, Florida, and Clinical Professor, \\ University of New Mexico School of Medicine, Albuquerque, New Mexico, USA
}

Prehistoric man left drawings of himself pierced by arrows. ${ }^{1}$ This means he was as aware of blood as he was of his own limbs. The flint implements he used as tools and weapons distinguished him from other creatures and contributed to the violence of his era. As he hunted food and fought enemies, he observed bleeding and the properties of blood. A cut, received or inflicted, yielded a vivid red color. If the cut was shallow, there was little blood. But if the cut was deep, a red torrent flowing from the stricken victim quickly led to death, with shed blood congealed and darkening in the sun. Fatal hemorrhage was commonplace. Nonetheless, the sight must have been fearful and possibly existential as life flowed red out of the body of an enemy or a wounded animal. ${ }^{2}$ It is no wonder, then, that at the dawn of recorded history, blood was already celebrated in religious rites and rituals as a life-giving force.

The cultural expressions of primitive and ancient societies, though separated by time or space, can be strikingly similar. Whether these expressions emerged independently or were diffused about the world by unknown voyagers will probably always remain clouded in mystery. ${ }^{2}$ Nonetheless, there is a common thread in the ancient rituals that celebrate blood as a mystical vital principle. In Leviticus 17:11, "the life of the flesh is in the blood," and the Chinese Neiching (circa 1000 BC) claims the blood contains the soul. ${ }^{2}$ Pre-Columbian North American Indians bled their bodies "of its greatest power" as self-punishment, ${ }^{3}$ Egyptians took blood baths as a recuperative measure, and Romans drank the blood of fallen gladiators in an effort to cure epilepsy. ${ }^{4}$ The Romans also practiced a ceremony called taurobolium-a blood bath for spiritual restoration. A citizen seeking spiritual rebirth descended into a pit or fossa sanguinis. Above him on a platform, a priest sacrificed a bull, and the animal's blood cascaded down in a shower upon the beneficiary. Then, in a powerful visual image, the subject emerged up from the other end of the pit, covered with blood and reborn. ${ }^{1}$

Rossi's Principles of Transfusion Medicine, 4th edn. Edited by T. L. Simon, E. L. Snyder, B. G. Solheim, C. P. Stowell, R. G. Strauss and M. Petrides. ๑) 2009 AABB published by Blackwell Publishing, ISBN: 978-1-4051-7588-3.
The legend of Medea and Aeson taken from Ovid's Metamorphoses and quoted in Bulfinch's Mythology $y^{5}$ also ascribed rejuvenating powers to blood. Jason asked Medea to "take some years off his life and add them to those of his father Aeson." Medea, however, pursued an alternative course. She prepared a cauldron with the blood of a sacrificed black sheep. To this, she added magic herbs, hoarfrost gathered by moonlight, the entrails of a wolf, and many other things "without a name." The boiling cauldron was stirred with a withered olive branch, which became green and full of leaves and young olives when it was withdrawn. Seeing that all was ready,

Medea cut the throat of the old man and let out all his blood, and poured into his mouth and into his wound the juices of her cauldron. As soon as he had imbibed them, his hair and beard laid by their whiteness and assumed the blackness of youth; his paleness and emaciation were gone; his veins were full of blood, his limbs of vigour and robustness. Aeson is amazed at himself and remembers that such as he now is, he was in his youthful days, 40 years before.

This legend seems to echo in the apocryphal story of Pope Innocent VIII, who is said to have received the blood of three young boys in 1492 while on his deathbed. As the story goes, a physician attempted to save the pope's life by using blood drawn from three boys 10 years of age, all of whom died soon thereafter. Some 19th-century versions of this tale suggest the blood was transfused. However, earlier renditions more plausibly suggest that the blood was intended for a potion to be taken by mouth. In any event, there is no evidence the pope actually received any blood in any form. 6 ,7

The folklore that flowed with blood was not accompanied by a great deal of accurate information. The ancient Greeks believed that blood formed in the heart and passed through the veins to the rest of the body, where it was consumed. Arteries were part of an independent system transporting air from the lungs. Although Erasistratos (circa $270 \mathrm{BC}$ ) had imagined the heart as a pump, his idea was ahead of its time. As long as veins and arteries were dead-end channels transporting blood and air, there was little need for a pump in the system. Although Galen (131-201 AD) finally proved that arteries contain blood, communication with 
the venous system was not suspected. Blood, formed in the liver, merely passed through the blood vessels and heart on its way to the periphery. ${ }^{1}$ These teachings remained in place for 1400 years until they were swept away in 1628 by Harvey's discovery of the circulation.

The realization that blood moved in a circulating stream opened the way to experiments on vascular infusion. In 1642 George von Wahrendorff injected wine ${ }^{8}$ —and in 1656 Christopher Wren and Robert Boyle injected opium and other drugs ${ }^{9}$ intravenously into dogs. The latter studies, performed at Oxford, were the inspiration for Richard Lower's experiments in animal transfusion.

\section{The First Animal Transfusion}

Richard Lower (1631-1691) was a student at Oxford when Christopher Wren and Robert Boyle began their experiments on infusion. In due course, Lower joined their scientific group and studied the intravenous injection of opiates, emetics, and other substances into living animals. ${ }^{10}$ In time, the transfusion of blood itself became the objective. The announcement of the first successful transfusion, performed by Richard Lower at Oxford in February 1665, was published on November 19, 1666, in the Philosophical Transactions of the Royal Society Transactions (Transactions) in a short notation titled, "The Success of the Experiment of Transfusing the Blood of One Animal into Another." 11 The entire notation is as follows ${ }^{11}$ :

This experiment, hitherto look'd upon to be of an almost insurmountable difficulty, hath been of late very successfully perform'd not only at Oxford, by the directions of that expert anatomist Dr. Lower, but also in London, by order of the R. Society, at their publick meeting in Gresham Colledge: the Description of the particulars whereof, and the Method of Operation is referred to the next opportunity.

The December 17, 1666 issue of the Transactions contained the full description as promised. ${ }^{12}$ It was taken from a letter ${ }^{13}$ written by Lower to Robert Boyle on July 6, 1666, in which Lower described direct transfusion from the carotid artery of one dog to the jugular vein of another. After describing the insertion of quills into the blood vessels of the donor and recipient dogs, Lower wrote ${ }^{13}$ :

When you have done this you may lay the dogs on their side and fasten them densely together as best you may to insure the connection of the two quills. Quickly tighten the noose around the neck of the receiving animal as in venasection, or at all events compress the vein on the opposite side of the neck with your finger, then take out the stopper and open the upper jugular quill so that while the foreign blood is flowing into the lower quill, the animal's own blood flows out from the upper into suitable receptacles - until at last the second animal, amid howls, faintings, and spasms, finally loses its life together with its vital fluid.

When the tragedy is over, take both quills out of the jugular vein of the surviving animal, tie tightly with the former slipknots, and divide the vein. After the vessel has been divided, sew up the skin, slacken the cords binding the dog, and let it jump down from the table. It shakes itself a little, as though aroused from sleep, and runs away lively and strong, more active and vigorous perhaps, with the blood of its fellow than its own.

These studies inevitably led to the transfusion of animal blood to humans. In England, this occurred on November 23, 1667, when Lower and Edmund King transfused sheep blood into a man named Arthur Coga. ${ }^{14}$ Described by Samuel Pepys as "a little frantic," Coga was paid 20 shillings to accept this transfusion, with the expectation that it might have a beneficial "cooling" effect. One week later, Coga appeared before the society and claimed to be a new man, although Pepys concluded he was "cracked a little in the head." ${ }^{13}$ However, this was not the first transfusion performed in a human. The credit for that accomplishment belongs to JeanBaptiste Denis (1635-1704), who had performed the first human transfusion several months earlier in Paris.

\section{The First Animal-to-Human Transfusion}

The founding of the Royal Society in London in 1662 was followed in 1666 by the establishment of the Academie des Sciences in Paris under the patronage of King Louis XIV. The new Academie reviewed the English reports on transfusion with great interest. Denis probably read of Lower's experiments in the Journal des Savants on January 31, 1667, and he began his own studies approximately 1 month later. ${ }^{15,16}$ The first human transfusion was then performed on June 15, 1667, when Denis administered the blood of a lamb to a 15-year-old boy (Fig 1-1).

Although discovery of the circulation had suggested the idea of transfusion, indications for the procedure remained uninformed. Transfusion was still thought to alter behavior and possibly achieve rejuvenation. The blood of young dogs made old dogs seem frisky; the blood of lions was proposed as a cure for cowardice; and 5 months later, Arthur Coga would receive a transfusion of sheep blood because of its presumed "cooling" effect. Denis used animal blood for transfusion because he thought it was "less full of impurities"17:

Sadness, Envy, Anger, Melancholy, Disquiet and generally all the Passions, are as so many causes which trouble the life of man, and corrupt the whole substance of the blood: Whereas the life of Brutes is much more regular, and less subject to all these miseries. It is thus ironic that the symptoms of the first transfusion recipient may have been explained in part by profound anemia; the single transfusion of lamb blood may have produced temporary amelioration owing to increased oxygen transport. Denis described the case as follows ${ }^{17}$ :

On the 15 of this Moneth, we hapned upon a Youth aged between 15 and 16 years, who had for above two moneths bin tormented with a contumacious and violent fever, which obliged his Physitians to bleed him 20 times, in order to asswage the excessive heat. 
Before this disease, he was not observed to be of a lumpish dull spirit, his memory was happy enough, and he seem'd chearful and nimble enough in body; but since the violence of this fever, his wit seem'd wholly sunk, his memory perfectly lost, and his body so heavy and drowsie that he was not fit for anything. I beheld him fall asleep as he sate at dinner, as he was eating his Breakfast, and in all occurrences where men seem most unlikely to sleep. If he went to bed at nine of the clock in the Evening, he needed to be wakened several times before he could be got to rise by nine the next morning, and he pass'd the rest of the day in an incredible stupidity.

I attributed all these changes to the great evacuations of blood, the Physitians had been oblig'd to make for saving his life.

Three ounces of the boy's blood were exchanged for 9 ounces of lamb arterial blood. Several hours later the boy arose, and "for the rest of the day, he spent it with much more liveliness than ordinary." Thus the first human transfusion, which was heterologous, was accomplished without any evident unfavorable effect.

This report stimulated a firestorm of controversy over priority of discovery. ${ }^{18,19}$ The letter by Denis was published in the Transactions on July 22, 1667, while the editor, Henry Oldenburg, was imprisoned in the Tower of London. Oldenburg, following some critical comments concerning the Anglo-Dutch War then in progress (1665-1667), had been arrested under a warrant issued June 20, 1667. After his release 2 months later, Oldenburg returned to his editorial post and found the letter published in his absence. He took offense at Denis's opening statement, which claimed that the French had conceived of transfusion "about ten years agoe, in the illustrious Society of Virtuosi ...” (Fig 1-1). This seemed to deny the English contributions to the field. Oldenburg cited these omissions in an issue of the Transactions published September 23, 1667, "for the Months of July, August, and September." By numbering this issue 27 and beginning pagination with 489, Oldenburg attempted to suppress the letter by Denis. ${ }^{18}$ However, as is evident, this did not ultimately succeed. Nonetheless, subsequent events created even greater difficulties for Denis.

Although the first two subjects who underwent transfusion by Denis were not adversely affected, the third and fourth recipients died. The death of the third subject was easily attributable to other causes. However, the fourth case initiated a sequence of events that put an end to transfusion for 150 years.

Anthony du Mauroy was a 34-year-old man who suffered from intermittent bouts of maniacal behavior. On December 19, 1667, Denis and his assistant Paul Emmerez removed 10 ounces of the man's blood and replaced it with 5 or 6 ounces of blood from the femoral artery of a calf. Failing to note any apparent improvement, they repeated the transfusion 2 days later. After the second transfusion, du Mauroy experienced a classic transfusion reaction ${ }^{20}$ :

His pulse rose presently, and soon after we observ'd a plentiful sweat over all his face. His pulse varied extremely at this instant, and he complain'd of great pains in his kidneys and that he was not well in his stomach.

\section{$\left(4^{89}\right)$ $N$ Nambiz. A LE T TER Concerning a new way of curing fundry difeafes by Transfufion of Blood, Written to Monfieur de MON TMOR, Counfellor to the French King, and Mafter of Requelts.}

\section{By J: DENIS Profeffor of Philofophy, and the Mathematicks.}

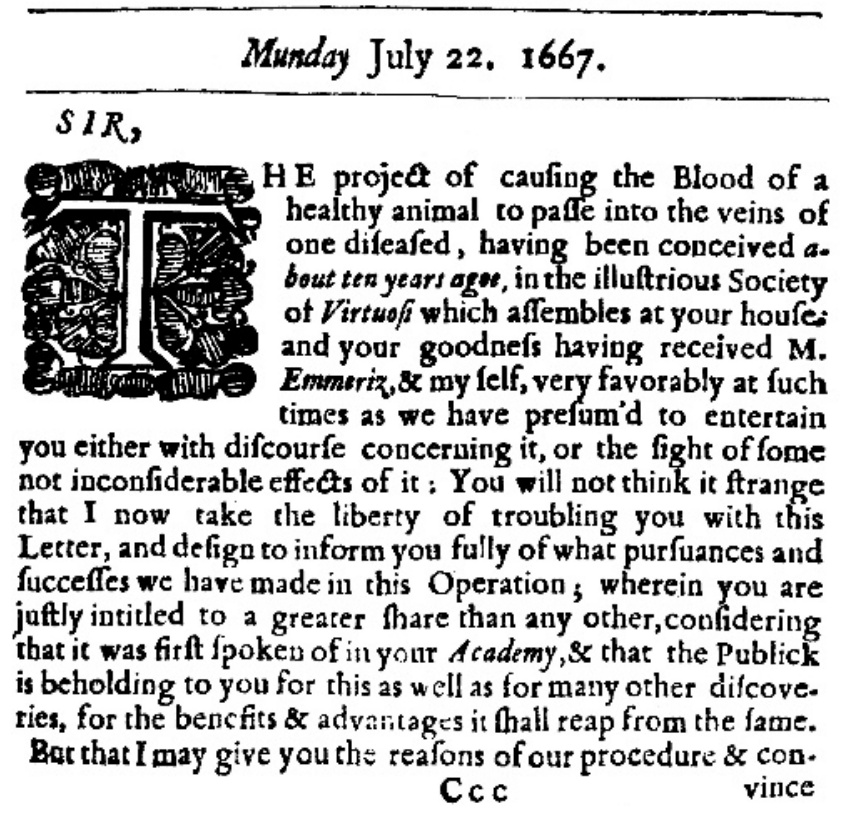

Figure 1-1. The first human transfusion. ${ }^{17}$

Du Mauroy fell asleep at about 10 o'clock in the evening. He awoke the following morning and "made a great glass full of urine, of a colour as black, as if it had been mixed with the soot of chimneys." 20 Two months later, the patient again became maniacal, and his wife again sought transfusion therapy. Denis was reluctant but finally gave in to her urgings. However, the transfusion could not be accomplished, and du Mauroy died the next evening.

The physicians of Paris strongly disapproved of the experiments in transfusion. Three of them approached du Mauroy's widow and encouraged her to lodge a malpractice complaint against Denis. She instead went to Denis and attempted to extort money from him in return for her silence. Denis refused and filed a complaint before the Lieutenant in Criminal Causes. During the subsequent hearing, evidence was introduced to indicate that Madame du Mauroy had poisoned her husband with arsenic. In a judgment handed down at the Chatelet in Paris on April 17, 1668, Denis was exonerated, and the woman was held for trial. The court also stipulated "that for the future no Transfusion should 
be made upon any Human Body but by the approbation of the Physicians of the Parisian Faculty." ${ }^{21}$ At this point, transfusion research went into decline, and within 10 years it was prohibited in both France and England.

\section{The Beginnings of Modern Transfusion}

After the edict that ended transfusion in the 17th century, the technique lay dormant for 150 years. Stimulated by earlier experiments by Leacock, transfusion was "resuscitated" and placed on a rational basis by James Blundell (1790-1877), a London obstetrician who had received his medical degree from the University of Edinburgh. ${ }^{22}$ Soon after graduation, Blundell accepted a post in physiology and midwifery at Guy's Hospital. It was there that he began the experiments on transfusion that led to its rebirth. The frequency of postpartum hemorrhage and death troubled Blundell. In 1818 he wrote ${ }^{23}$ :

A few months ago I was requested to visit a woman who was sinking under uterine hemorrhage ... Her fate was decided, and notwithstanding every exertion of the medical attendants, she died in the course of two hours.

Reflecting afterwards on this melancholy scene ..., I could not forbear considering, that the patient might very probably have been saved by transfusion; and that ... the vessels might have been replenished by means of the syringe with facility and prompitude.

This opening statement introduced Blundell's epoch-making study titled "Experiments on the Transfusion of Blood by the Syringe." 23 (See Fig 1-2.) Blundell described in detail a series of animal experiments. He demonstrated that a syringe could be

\section{EXPERIMENTS}

ON TIE

\section{TRANSFUSION OF BLOOD}

BY THE

\section{SY R I N GE.}

BY JAMES BLUNDELL, M.D. LECTURER ON PHYSIOLOGY AT GLY'S HOSPITAX.

COMMLNICATED

BX MR. CLINE.

Rend Feb. 3, 181 s.

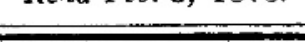

Figure 1-2. The beginnings of modern transfusion. ${ }^{23}$ used effectively to perform transfusion, that the lethal effects of arterial exsanguination could be reversed by the transfusion of either venous or arterial blood, and that the injection of 5 drams $(20 \mathrm{cc})$ of air into the veins of a small dog was not fatal but transfusion across species ultimately was lethal to the recipient. ${ }^{23}$ Thus Blundell was the first to state clearly that only human blood should be used for human transfusion. The latter conclusion was confirmed in France by Dumas and Prevost, who demonstrated that the infusion of heterologous blood into an exsanguinated animal produced only temporary improvement and was followed by death within 6 days. ${ }^{24}$ These scientific studies provided the basis for Blundell's subsequent efforts in clinical transfusion.

The first well-documented transfusion with human blood took place on September 26, 1818. ${ }^{25}$ The patient was an extremely emaciated man in his mid-thirties who had pyloric obstruction caused by carcinoma. He received 12 to 14 ounces of blood in the course of 30 or 40 minutes. Despite initial apparent improvement, the patient died 2 days later. Transfusion in the treatment of women with postpartum hemorrhage was more successful. In all, Blundell performed 10 transfusions, of which five were successful. Three of the unsuccessful transfusions were performed on moribund patients; the fourth was performed on a patient with puerperal sepsis; and the fifth was performed on the aforementioned patient with terminal carcinoma. Four of the successful transfusions were given for postpartum hemorrhage, and the fifth was administered to a boy who bled after amputation. ${ }^{22}$ Blundell also devised various instruments for the performance of transfusion. They included an "impellor," which collected blood in a warmed cup and "impelled" the blood into the recipient via an attached syringe, and a "gravitator"26 (Fig 1-3), which received blood and delivered it by gravity through a long vertical cannula.

The writings of Blundell provided evidence against the use of animal blood in humans and established rational indications for transfusion. However, the gravitator (Fig 1-3) graphically demonstrated the technical problems that remained to be solved. Blood from the donor, typically the patient's husband, flowed into a funnel-like device and down a flexible cannula into the patient's vein "with as little exposure as possible to air, cold and inanimate surface." 25 The amount of blood transfused was estimated from the amount spilled into the apparatus by the donor. In this clinical atmosphere, charged with apprehension and anxiety, the amount of blood issuing from a donor easily could be overstated. Clotting within the apparatus then ensured that only a portion of that blood actually reached the patient. Thus the amount of blood actually transfused may have been seriously overestimated. This may explain the apparent absence of transfusion reactions. Alternatively, reactions may have been unrecognized. Patients who underwent transfusion frequently were agonal. As Blundell ${ }^{26}$ stated, "It seems right, as the operation now stands, to confine transfusion to the first class of cases only, namely, those in which there seems to be no hope for the patient, unless blood can be thrown into the veins." Under these circumstances, "symptoms" associated with an "unsuccessful" transfusion might be ascribed to the agonal state rather than the 
transfusion itself. For a time, the problem of coagulation during transfusion was circumvented by the use of defibrinated blood. This undoubtedly increased the amount of blood actually transfused. However, there were numerous deaths. Interestingly, these deaths were attributed to intravascular coagulation when in actuality they were probably fatal hemolytic reactions caused by the infusion of incompatible blood. ${ }^{27}$

Transfusion at the end of the 19th century, therefore, was neither safe nor efficient. The following description, written in 1884 , illustrates this point ${ }^{28}$ :

Students, with smiling faces, are rapidly leaving the theatre of one of our metropolitan hospitals. The most brilliant operator of the day has just performed immediate transfusion with the greatest success. By means of a very beautiful instrument, the most complex and ingenious that modern science has yet produced, a skilful surgeon has transfused half a pint, or perhaps a pint, of blood from a healthy individual to a fellow creature profoundly collapsed from the effects of severe hemorrhage. Some little difficulty was experienced prior to the operation, as one of the many stop-cocks of the

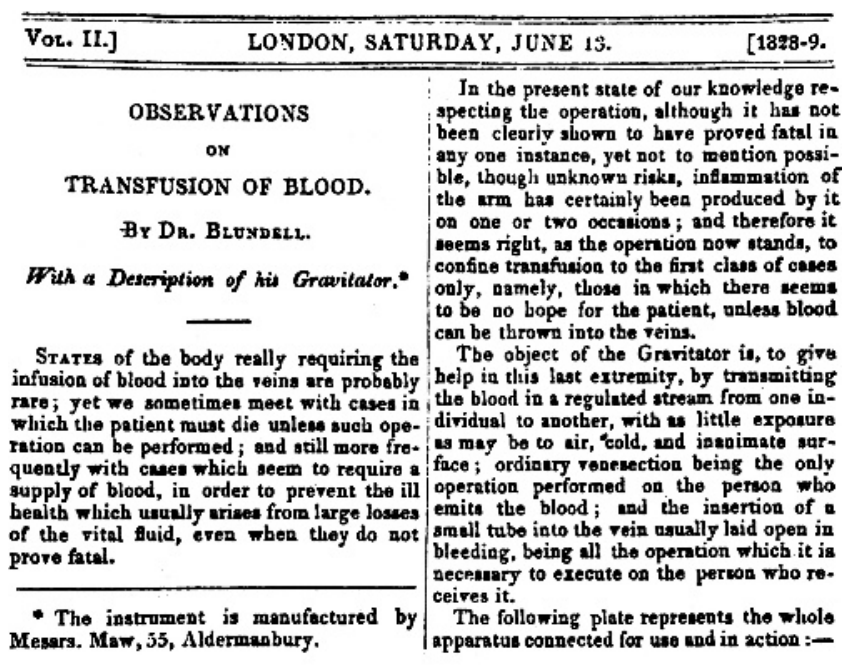

Tab. 1 .

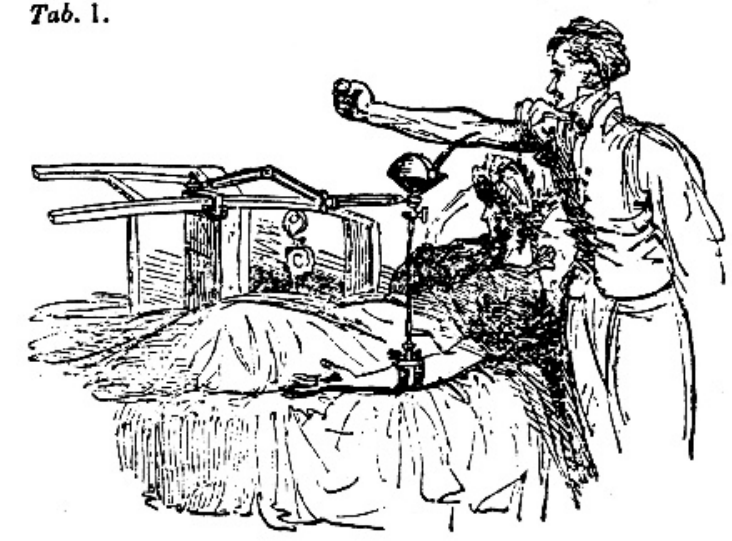

No. 30!s.

$Y$ transfusion apparatus was found to work stiffly; but this error was quickly rectified by a mechanic in attendance. Towards the close of the operation the blood-donor, a powerful and heavy young man, swooned. Two porters carried him on a stretcher into an adjoining room.

In the latter half of the 19th century, there were many attempts to render transfusion a more predictable and less arduous procedure. In 1869, Braxton-Hicks, ${ }^{29}$ using blood anticoagulated with phosphate solutions, performed a number of transfusions on women with obstetric bleeding. Many of the patients were in extremis, and ultimately all died. Unfortunately, a detailed description of terminal symptoms was not provided. ${ }^{29}$ Some investigators attempted to rejuvenate animal-to-human transfusion, and Oscar Hasse persisted in this approach despite disastrous results. Studies by Emil Ponfick and by Leonard Landois finally put an end to this practice. Ponfick, in carefully controlled studies, confirmed the lethality of heterologous transfusion and identified the resulting hemoglobinuria along with its donor erythrocyte source. Landois documented the poor results of animal-to-human transfusion and demonstrated the lysis of sheep erythrocytes by human serum in vitro. ${ }^{8}$

Frustration with blood as a transfusion product led to even more bizarre innovations. From 1873 to 1880 , cow, goat, and even human milk was transfused as a blood substitute. ${ }^{30}$ The rationale derived from an earlier suggestion that the fat particles of milk could be converted into blood cells. Milk transfusion was particularly popular in the United States, ${ }^{30}$ where the practice of animal-to-human transfusion was recorded as late as $1890 .^{31}$ Fortunately, these astonishing practices were discontinued when saline solutions were introduced as "a life-saving measure" and "a substitute for the transfusion of blood." 32 A passage from an article written by Bull in $1884^{32}$ is particularly instructive:

The danger from loss of blood, even to two-thirds of its whole volume, lies in the disturbed relationship between the calibre of the vessels and the quantity of the blood contained therein, and not in the diminished number of red blood-corpuscles; and ... This danger concerns the volume of the injected fluids also, it being a matter of indifference whether they be albuminous or containing blood corpuscles or not....

Mercifully, volume replacement with saline solutions deflected attention from the unpredictable and still dangerous practice of blood transfusion. Accordingly, transfusions were abandoned until interest was rekindled by the scientific and technical advances of the early 20th century.

\section{The 20th Century}

The 20th century was ushered in by a truly monumental discovery. In 1900, Karl Landsteiner (1868-1943) observed that the sera of some persons agglutinated the red blood cells of others. This study, published in 1901 in the Wiener Klinische Wochenschrift ${ }^{33}$ (Fig 1-4), showed for the first time the cellular differences in

Figure 1-3. Blundell's gravitator. ${ }^{26}$ 


\section{Aus dem pathologisch-anatomischen Institute in Wien. Ueber Agglutinationserscheinungen normalen menschlichen Blutes.}

Von Dr. Kurl Landsteiner, Assistenten am pathologisch-anatomischen Institute.

Figure 1-4. Landsteiner's description of blood groups. ${ }^{33}$

individuals from the same species. In his article, Landsteiner wrote $^{34}$ :

In a number of cases (Group A) the serum reacts on the corpuscles of another group (B), but not, however, on those of group A, while, again, the corpuscles of $A$ will be influenced likewise by serum $B$. The serum of the third group (C) agglutinates the corpuscles of $A$ and $\mathrm{B}$, while the corpuscles of $\mathrm{C}$ will not be influenced by the sera of $\mathrm{A}$ and $\mathrm{B}$. The corpuscles are naturally apparently insensitive to the agglutinins which exist in the same serum.

With the identification of blood groups A, B, and C (subsequently renamed group $\mathrm{O}$ ) by Landsteiner and of group $\mathrm{AB}$ by Decastello and Sturli, ${ }^{35}$ the stage was set for the performance of safe transfusion. For this work, Landsteiner somewhat belatedly received the Nobel Prize in 1930. But even that high recognition does not adequately express the true magnitude of Landsteiner's discovery. His work was like a burst of light in a darkened room. He gave us our first glimpse of immunohematology and transplantation biology and provided the tools for important discoveries in genetics, anthropology, and forensic medicine. Viewed from this perspective, the identification of human blood groups is one of only a few scientific discoveries of the 20th century that changed all of our lives. ${ }^{34}$ Yet the translation of Landsteiner's discovery into transfusion practice took many years.

At the turn of the century, the effective transfer of blood from one person to another remained a formidable task. Clotting, still uncontrolled, quickly occluded transfusion devices and frustrated most efforts. In 1901 the methods used in transfusion were too primitive to demonstrate the importance of Landsteiner's discovery. Indeed, the study of in-vitro red cell agglutination may have seemed rather remote from the technical problems that demanded attention. An intermediate step was needed before the importance of Landsteiner's breakthrough could be perceived and the appropriate changes could be incorporated into practice. This process was initiated by Alexis Carrel (1873-1944), another Nobel laureate, who developed a surgical procedure that allowed direct transfusion through an arteriovenous anastomosis.

Carrel $^{36}$ introduced the technique of end-to-end vascular anastomosis with triple-threaded suture material. This procedure brought the ends of vessels in close apposition and preserved luminal continuity, thus avoiding leakage or thrombosis. This technique paved the way for successful organ transplantation and brought Carrel the Nobel Prize in 1912. It was also adapted by Carrel ${ }^{37}$ and others ${ }^{38,39}$ to the performance of transfusion. Crile ${ }^{38}$ introduced the use of a metal tube to facilitate placement of sutures, and Bernheim ${ }^{39}$ used a two-piece cannula to unite the artery to the vein (Fig 1-5). Because all of these procedures usually culminated in the

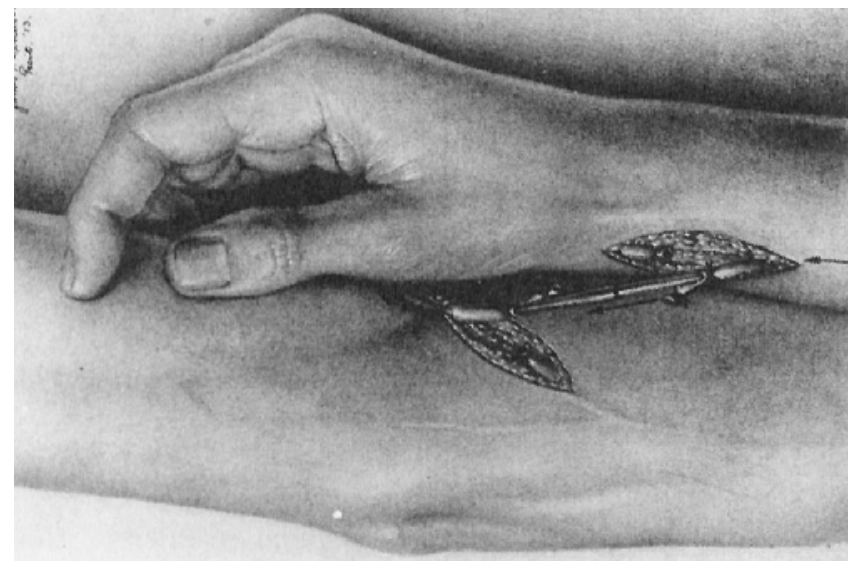

Figure 1-5. Direct transfusion by means of arteriovenous anastomosis through the two-pieced cannula of Bernheim. ${ }^{39}$

\section{A C.ASE OF FATAL HEJOLYSIS FOLLOWIYG DIRECT TRANSFUSION OF BLOOD BY ARTERIOVEXOUS ANASTOMOSIS.* \\ WILLIAM PEPPER, MD. \\ Inatructor in Sedletne, Cntreratty of Penneglvanle. \\ AxD \\ VERYER NISBET, M.D. \\ Assigtant Instructor in Jediclne. Eniveratey of Peaneslranis Assistant Director of the Willinm Pepper Laboratory of Cilnical Irediciae. \\ PIILAdELPUKa.}

Figure 1-6. Report of a fatal transfusion reaction. ${ }^{41}$

sacrifice of the two vessels, they were not performed frequently. Direct transfusion was also fraught with danger. In a passage written two decades later, the procedure was recalled in the following manner ${ }^{40}$ :

The direct artery to vein anastomosis was the best method available but was often very difficult or even unsuccessful. And, what was almost as bad, one never knew how much blood one had transfused at any moment or when to stop (unless the donor collapsed). (I remember one such collapse in which the donor almost died-and the surgeon needed to be revived.)

Despite these many difficulties, direct transfusion through an arteriovenous anastomosis for the first time efficiently transferred blood from one person to another. The process also disclosed fatal hemolytic reactions that were undeniably caused by transfusion $^{41}$ (Fig 1-6). However, the relation of these fatal reactions to Landsteiner's discovery was not recognized until Reuben Ottenberg (1882-1959) demonstrated the importance of compatibility testing.

Ottenberg's interest in transfusion began in 1906 while he was an intern at German (now Lenox Hill) Hospital in New York. There Ottenberg learned of Landsteiner's discovery and in 1907 began pretransfusion compatibility testing. ${ }^{42}$ Ottenberg accepted an appointment at Mount Sinai Hospital the next year and continued 


\section{ACCIDENTS IN TRANSFLSION}

THEIR PREVENTION BY PRELIMINATY BLOOD EXANLITION: BASED ON AN EXPERIENCE OF ONE HUNDBED TWENTY-EIGIIT TRANSFUSIONS * REUBEN OTTENBERG, M.D. AND DAVID J. KALISKI, MI.D. SEW YozK

Accidents following transfusion have been sufficiently frequent to make many medical men hesitate to advise transfusion, except in desperate cases. It has been our opinion since we began making observations on this question in 1908 that such accidents could be prevented by careful preliminary tests, leading to the exclusion of agglutinative or hemolytic donors. Our observations on over 125 cases have confirmed this view and we believe that untoward symptoms can be prevented with absolute certainty.

Figure 1-7. Report of the importance of testing before transfusion. ${ }^{43}$

his studies on transfusion. In 1913, Ottenberg published the report that conclusively demonstrated the importance of preliminary blood testing for the prevention of transfusion "accidents" 43 (Fig 17). This was not Ottenberg's only contribution. He observed the mendelian inheritance of blood groups, ${ }^{44}$ and he was the first to recognize the relative unimportance of donor antibodies and consequently the "universal" utility of type O blood donors. ${ }^{45}$

Further advances in immunohematology were to occur in succeeding decades. The $\mathrm{M}, \mathrm{N}$, and $\mathrm{P}$ systems were described in the period between 1927 and $1947 .{ }^{46}$ The Rh system was discovered in connection with an unusual transfusion reaction. In 1939, Levine and Stetson ${ }^{47}$ described an immediate reaction in a group $\mathrm{O}$ woman who had received her husband's group O blood soon after delivery of a stillborn fetus with erythroblastosis. This sequence of events suggested that the infant had inherited a red cell agglutinogen from the father that was foreign to the mother. At about the same time, Landsteiner and Wiener ${ }^{48}$ harvested a rhesus monkey red cell antibody from immunized guinea pigs and rabbits. This antibody agglutinated $85 \%$ of human red cell samples (Rh-positive) and left 15\% (Rh-negative) unaffected. When the experimentally induced antibody was tested in parallel with the serum from Levine's patient, a similar positive and negative distribution was observed, and the Rh system had been discovered. Other red cell antigen systems were subsequently described, but when $\mathrm{Rh}$ Immune Globulin was introduced as a preventive measure for hemolytic disease of the newborn, it became one of the major public health advances of the century.

Despite the introduction of compatibility testing by Ottenberg, transfusion could not be performed frequently as long as arteriovenous anastomosis remained the procedure of choice. Using this method, Ottenberg needed 5 years (Fig 1-7) to accumulate the 128 transfusions he reported in his study on pretransfusion testing. ${ }^{43}$ New techniques, such as Unger's two-syringe method introduced in $1915^{49}$ (Fig 1-8), eventually put an end to transfusion by means of arteriovenous anastomosis. However, transfusions did not become commonplace until anticoagulants were developed and direct methods of transfusion were rendered obsolete.

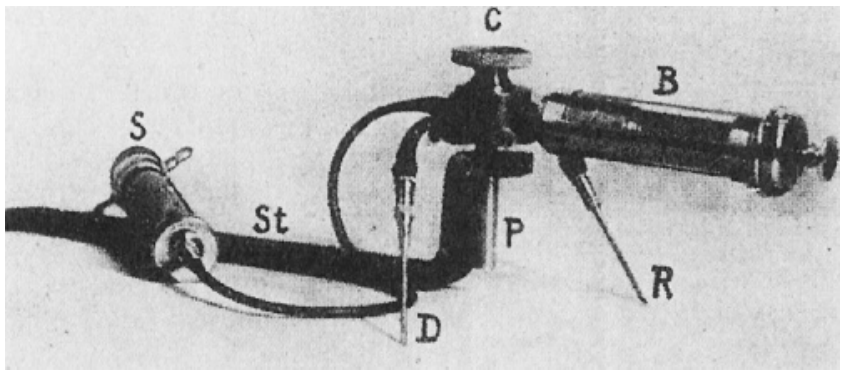

Figure 1-8. Apparatus for Unger's two-syringe, four-way stopcock method of indirect transfusion. ${ }^{49}$

\section{Anticoagulants, the Blood Bank, and Component Therapy}

The anticoagulant action of sodium citrate completely transformed the practice of transfusion. Early reports from Belgium ${ }^{50}$ and Argentina ${ }^{51}$ were followed by the work of Lewisohn ${ }^{52}$ that established the optimal citrate concentration for anticoagulation. The work of Weil ${ }^{53}$ then demonstrated the feasibility of refrigerated storage. Subsequently, Rous and Turner ${ }^{54}$ developed the anticoagulant solution that was used during World War I. ${ }^{55}$ Despite its very large volume, this solution remained the anticoagulant of choice until World War II, when Loutit and Mollison ${ }^{56}$ developed an acid-citrate-dextrose (ACD) solution. Used in a ratio of $70 \mathrm{~mL}$ ACD to $450 \mathrm{~mL}$ blood, ACD provided 3 to 4 weeks of preservation of a more concentrated red cell infusion. Thus, the two world wars were the stimuli for the development of citrate anticoagulants and the introduction of indirect transfusion. ${ }^{46}$ For the first time, the donation process could be separated, in time and place, from the actual transfusion. Blood drawn and set aside now awaited the emergence of systems of storage and distribution. Again, it was the provision of medical support during armed conflict that stimulated these developments.

A blood transfusion service, organized by the Republican Army during the Spanish Civil War (1936-1939), collected 9000 L of blood in citrate-dextrose anticoagulant for the treatment of battle casualties. ${ }^{57}$ At about that same time, Fantus ${ }^{58}$ began operation of the first hospital blood bank at Cook County Hospital in Chicago. His interest had been stimulated by Yudin's report ${ }^{59}$ on the use of cadaveric blood in Russia. Apart from certain scruples attached to the use of cadaveric blood, Fantus reasoned that a transfusion service based on such a limited source of supply would be impractical. Accordingly, he established the principle of a "blood bank" from which blood could be withdrawn, provided it had previously been deposited. As Fantus ${ }^{58}$ himself stated, "just as one cannot draw money from a bank unless one has deposited some, so the blood preservation department cannot supply blood unless as much comes in as goes out. The term 'blood bank' is not a mere metaphor." The development of anticoagulants and the concept of blood banks provided an infrastructure upon which a more elaborate blood services organization could be built. World War II was the catalyst for these further developments. 
At the beginning of World War II, blood procurement programs were greatly expanded. ${ }^{46}$ In Great Britain an efficient system had been developed through the organization of regional centers. When the war started, these centers, already in place, were able to increase their level of operation. In the United States the use of plasma in the management of shock had led to the development of plasma collection facilities. ${ }^{60}$ The efficient longterm storage of plasma had been further facilitated by the process of lyophilization developed by Flosdorf and Mudd and the introduction of ABO-independent "universal" plasma produced by pooling of several thousand units of plasma. ${ }^{61}$ In 1940, the United States organized a program for the collection of blood and the shipment of plasma to Europe. The American Red Cross, through its local chapters, participated in the project, which collected 13 million units by the end of the war. ${ }^{46}$

The national program of the American Red Cross ceased at the end of the war. However, many of the local chapters continued to help recruit donors for local blood banks, and in 1948, the first regional Red Cross blood center was begun in Rochester, New York. By 1949-1950 in the United States, the blood procurement system included 1500 hospital blood banks, 1100 of which performed all blood bank functions. There were 46 nonhospital blood banks and 31 Red Cross regional blood centers. By 1962, these numbers had grown to 4400 hospital blood banks, 123 nonhospital blood banks, and 55 American Red Cross regional blood centers, and the number of units collected had grown to between 5 and 6 million per year. ${ }^{62}$

During this time, blood was collected through steel needles and rubber tubing into rubber-stoppered bottles. After washing and resterilization, the materials were reused. On occasion, "vacuum bottles" were used to speed up the collection. However, the high incidence of pyrogenic reactions soon led to the development of disposable plastic blood collection equipment.

In a classic article written in 1952, Walter and Murphy ${ }^{63}$ described a closed, gravity technique for whole blood preservation. They used a laminar flow phlebotomy needle, an interval donor tube, and a collapsible bag of polyvinyl resin designed so that the unit could be assembled and ready for use after sterilization with steam. The polyvinyl resin was chemically inert to biologic fluids and nonirritating to tissue. Soon thereafter, Gibson et $\mathrm{al}^{64}$ demonstrated that plastic systems were more flexible and allowed removal of plasma after sedimentation or centrifugation. In time, glass was replaced with plastic, and component therapy began to emerge. This development was enhanced by the US military's need to reduce the weight and breakage of blood bottles during shipment in the Korean War.

Component and derivative therapy began during World War II when Edwin J. Cohn and his collaborators developed the cold ethanol method of plasma fractionation. ${ }^{65}$ As a result of their work, albumin, globulin, and fibrinogen became available for clinical use. As plastic equipment replaced glass, component separation became a more widespread practice, and the introduction of automated cell separators provided even greater capabilities in this area.
Clotting factor concentrates for the treatment of patients with hemophilia and other hemorrhagic disorders also were developed during the postwar era. Although antihemophilic globulin had been described in $1937,{ }^{66}$ unconcentrated plasma was the only therapeutic material until Pool discovered that Factor VIII could be harvested in the cryoprecipitable fraction of blood. ${ }^{67}$ This resulted in the development of cryoprecipitate, which was introduced in 1965 for the management of hemophilia. Pool showed that cryoprecipitate could be made in a closed-bag system and urged its harvest from as many donations as possible. The development of cryoprecipitate and other concentrates was the dawn of a golden age in the care of patients with hemophilia. Self-infusion programs, made possible by technologic advances in plasma fractionation, allowed early therapy and greatly reduced disability and unemployment. This golden age came abruptly to an end with the appearance of the AIDS virus.

\section{Transfusion in the Age of Technology}

In contrast to the long ledger of lives lost in previous centuries because of the lack of blood, transfusion in the 20th century saved countless lives. In 1937, during those early halcyon days of transfusion, Ottenberg wrote ${ }^{40}$ :

Today transfusion has become so safe and so easy to do that it is seldom omitted in any case in which it may be of benefit. Indeed the chief problem it presents is the finding of the large sums of money needed for the professional donors who now provide most of the blood.

It is ironic that Ottenberg's statement should refer to paid donors and foreshadow difficulties yet to come. However, experience to that point had not revealed the problem of viral disease transmission. More transfusions would have to be administered before that problem would be perceived.

After the introduction of anticoagulants, blood transfusions were given in progressively increasing numbers. At Mount Sinai Hospital in New York, the number of blood transfusions administered between 1923 and 1953 increased 20-fold ${ }^{68,69}$ (Table 1-1). This increase was particularly notable after the establishment of blood banks. It was during this period that Beeson wrote his classic description of transfusion-transmitted hepatitis ${ }^{70}$ (Fig 1-9). He had been alerted to the problem by the outbreaks of jaundice that followed inoculation programs with human serum during World War II. Thus blood transfusion entered a new era. Blood components not only saved lives but also transmitted disease. The discovery of the Australian antigen ${ }^{71}$ and the subsequent definition of hepatitis A virus and B virus (HBV) still left residual non-A and non-B disease, ${ }^{72}$ a gap that has been largely filled by the discovery of the hepatitis $\mathrm{C}$ virus (HCV). ${ }^{73}$ However, it was the outbreak of AIDS that galvanized public attention to blood transfusion.

The AIDS epidemic was first recognized in the United States, and the first case of AIDS associated with transfusion was observed in a 20 -month-old infant. ${ }^{74}$ Subsequently the suspicion that AIDS 
Table 1-1. Increase in the Number of Blood Transfusions at Mount Sinai Hospital, New York, 1923-1953

\begin{tabular}{ll}
\hline Year & No. of Transfusions \\
\hline 1923 & 143 \\
1932 & 477 \\
1935 & 794 \\
1938 & (Blood bank started) \\
1941 & 2097 \\
1952 & 2874 \\
1953 & 3179 \\
\hline
\end{tabular}

Adapted from Lewisohn. ${ }^{68}$

\section{JAUNDICE OCCURRING ONE TO FOUR MONTHS AFTER TRANSFUSION OF BLOOD OR PLASMA REPORT OF SEVEN CASES}

PAUL B. BEESON, M.D. ATLANTA, Ga.

The purpose of this communication is to report 7 cases of jaundice which occurred one to four months after transfusions of whole blood or plasma and to suggest that these illnesses were probably caused by the transfusions.

Figure 1-9. The first description of posttransfusion hepatitis. Used with permission from Beeson (JAMA). ${ }^{70}$ Copyright 1943, American Medical Association.

could be transmitted by means of transfusion was confirmed. ${ }^{75}$ The human immunodeficiency virus (HIV) was identified, ${ }^{76}$ and an effective test to detect the HIV antibody was developed. ${ }^{76}$

\section{Concern for Blood Safety}

Since 1943, transfusion therapy has been shadowed by the specter of disease transmission. In that year, Beeson described posttransfusion hepatitis and unveiled a problem that has grown with time. As transfusion increased, so did disease transmission. In 1962, the connection between paid donations and posttransfusion hepatitis was made. ${ }^{77}$ A decade later, the National Blood Policy mandated a voluntary donation system in the United States. And yet, blood usage continued to increase.

Concern about posttransfusion hepatitis was not sufficient to decrease the number of transfusions. Although the use of whole blood declined as blood components became more popular, total blood use in the United States doubled between 1971 and 1980 (Table 1-2). ${ }^{78-84}$ This pattern changed as the emergence of AIDS exposed all segments of society to a revealing light.

AIDS probably arose in Africa in the 1960s and spread quietly for years before it was detected. By 1980 an estimated 100,000 persons were infected, and by 1981, when the first cases were
Table 1-2. Transfusions in the United States (in Millions of Units) ${ }^{78-84}$

\begin{tabular}{llclr}
\hline Year & $\begin{array}{l}\text { Whole Blood and } \\
\text { Red Blood Cells }\end{array}$ & Platelets & Plasma & Total \\
\hline 1971 & 6.32 & 0.41 & 0.18 & \\
1979 & 9.47 & 2.22 & 1.29 & 12.98 \\
1980 & 9.99 & 3.19 & 1.54 & 14.72 \\
1982 & 11.47 & 4.18 & 1.95 & 17.60 \\
1984 & 11.98 & 5.53 & 2.26 & 19.77 \\
1986 & 12.16 & 6.30 & 2.18 & 20.64 \\
1987 & 11.61 & 6.38 & 2.06 & 20.05 \\
1989 & 12.06 & 7.26 & 2.16 & 21.48 \\
1992 & 11.31 & 8.33 & 2.26 & 21.90 \\
1994 & 11.11 & 7.87 & 2.62 & 21.60 \\
1997 & 11.52 & 9.04 & 3.32 & 23.88 \\
1999 & 12.39 & 9.05 & 3.32 & 24.76 \\
2001 & 13.90 & 10.20 & 3.93 & 28.03 \\
2004 & 14.18 & 9.88 & 4.09 & 28.15 \\
2006 & 14.65 & 10.39 & 4.01 & 29.05 \\
\hline
\end{tabular}

reported, a worldwide pandemic lay just beneath the surface. ${ }^{85}$ The initial response of the public and officials seemed trifling and insufficient as the outbreak grew to proportions few had foreseen. Criticism was levied against the news media for initially ignoring the story, the government for delay in acknowledging the problem, gay civil rights groups for resistance to epidemiologic measures, research scientists for unseemly competition, blood services for delayed response in a time of crisis, and the US Food and Drug Administration (FDA) for inadequate regulatory activity. Historians with the perspective of time will determine whether there really were more villains than the virus itself. ${ }^{86}$

Improved donor screening and increased donation testing have greatly decreased the risk of disease transmission and rendered the blood supply safer than it has ever been. ${ }^{86}$ Nonetheless, the realization that transfusion can transmit an almost invariably fatal disease had a chilling effect on the public. Two major changes in blood services have occurred in the aftermath of the AIDS epidemic. The FDA, using pharmaceutical manufacturing criteria not "tailored to ... blood banks," has become more aggressive in regulatory actions against blood collection establishments. ${ }^{87}$ And, finally, blood use moderated for approximately 10 years. Through the 1980s and early 1990s, red cell and plasma transfusion peaked and began to stabilize (Table 1-2). Only platelet use and human progenitor cell transplantation, driven by the demands of cancer chemotherapy, continued to increase. ${ }^{79-81}$ Educational programs to encourage judicious use of blood have been initiated, and they have been favorably received by practicing physicians.

Relentless public pressure for a "zero risk" blood supply resulted in dividends through continued scientific and technologic improvements. Enhanced sensitivity and better use of serologic testing, along with improved scrutiny of donors, resulted in major reductions in risk of transmitted disease by the mid-1990s. ${ }^{88}$ Discovery that pools of units subjected to nucleic acid testing almost closed 
the window for HIV and HCV virus resulted in application of this testing for both whole blood and plasma donations beginning between 1998 and 2000. ${ }^{89}$ This, combined with virus reduction and inactivation of the final product, resulted in plasma derivatives that have not transmitted AIDS or hepatitis since $1994 .{ }^{90}$ For whole blood and platelet components, risks have become low. A solvent/ detergent-treated fresh frozen plasma component is used in Europe but not in the United States.

With the reduction in the risk of viral transmission, the focus in the developed world has shifted to transfusion-related acute lung injury-possibly from recipient-directed leukocyte antibodies and lipid mediators in transfused plasma—and bacterial infection primarily occurring in room-temperature stored platelets. So that incremental gains can be made against these risks, the use of male plasma only and the culture of platelets before they are released are being discussed and considered in some areas and implemented in others. Geographic exclusions have been aimed at reducing the potential for variant CreutzfeldtJakob disease (vCJD) transmission by transfusion, although in the United States such occurrence seems highly unlikely. In many countries, universal leukocyte reduction has been a response to the vCJD risk. Ironically universal application of leukocyte reduction is probably ineffective for vCJD but has stimulated a controversy in the United States over its use for preventing other problems. $^{91}$

Finally, focus on the understanding, management, and prevention of medical errors in general might lead to progress against remaining nemesis hemolytic transfusion reactions caused by mistransfusion. Bar code technology at the bedside, commonly applied to prevent errors in medication administration, has shown efficacy in reducing transfusion errors. ${ }^{92}$ Radio-frequency identification shows further promise in error-prone situations such as operating rooms. ${ }^{93}$ Transfusion safety officers and hemovigilance systems are other initiatives being considered or instituted.

"Zero risk" has still not been achieved. Emerging global infections such as West Nile virus, Chagas' disease, and Chikungunya virus remain future potential threats and have encouraged further test development. Nevertheless, increased public and physician confidence in the safety of the blood supply (Table 1-3) combined with both increased aggressiveness of therapies and aging of the population resulted in increased blood use by 1999. For 2001 through 2006, total red cell transfusions in the United States increased by $5.4 \%$ and total platelet and plasma transfusions rose by $2 \%$ each. A significant decrease was seen in autologous transfusions $(47.4 \%){ }^{84}$

\section{Current Megatrends}

In the developed world, no cost has been spared in meeting public demands for blood safety. Service fees charged to hospitals by independent blood centers in the United States (Fig 1-10) illustrate the effect each new safety development has had on the cost of Red Blood Cells (RBCs). As the new millennium began, the
Table 1-3. Risk Estimates per Unit of Red Blood Cells Transfused in the United States, Ranked by Frequency

\begin{tabular}{ll}
\hline Type of Risk & Estimated Occurrence \\
\hline Urticaria & 1 in $50-100$ \\
Red cell allommunization & 1 in 100 \\
Febrile reaction & 1 in 300 \\
TRALI & 1 in 5000 \\
Hemolytic reaction & 1 in 6000 \\
Transfusion to the wrong recipient & 1 in $14,000-19,000$ \\
Anaphylaxis & 1 in $20,000-50,000$ \\
Hepatitis B virus & 1 in $100,000-200,000$ \\
HTLV-I/II & 1 in 641,000 \\
Hepatitis C virus & 1 in $1-2$ million \\
HIV & 1 in $2-3$ million \\
Malaria & 1 in 4 million \\
Bacterial contamination & 1 in 5 million \\
GVHD & Very rare, no estimates \\
\hline
\end{tabular}

TRALI = transfusion-related acute lung injury; HTLV-I/II = human Tcell lymphotropic virus, types I and II; HIV = human immunodeficiency virus; GVHD= graft-vs-host disease Adapted from Klein et al. ${ }^{94}$

mean payment for RBC units was $\$ 100$, and a leukocyte-reduced unit was $\$ 126$. By 2005 those had risen to $\$ 157$ and $\$ 188$ respectively, with significant annual increases. ${ }^{95}$

One group of researchers (committed to programs to reduce blood use) has published data suggesting that the societal cost of a unit of RBCs is $\$ 1400$ per unit taking into account not only the blood center fee but also hospital-related costs, costs of treating adverse reactions, litigation, lost productivity of donors, and hemovigilance. ${ }^{96}$ Although the figure might be overinflated, such work does highlight the ever increasing cost of this form of therapy to the patient and society.

In the underdeveloped world, the picture is quite different. The greatest blood need is for women hemorrhaging during childbirth, infants and children with anemia caused by malaria, and victims of trauma. In 80 of 172 countries responding to a World Health Organization (WHO) survey, fewer than $1 \%$ of the population donate blood. In sub-Saharan Africa, fewer than 3 million units of blood are collected annually for a population of more than 700 million. Of the 148 countries reporting data to WHO, 41 are unable to screen for minimum safety (HIV, HBV, HVC, and syphilis). WHO estimates that unsafe blood in these countries results in 16 million new infections with HBV, 5 million with HCV, and 160,000 with HIV each year (accounting for $5 \%-10 \%$ of the world's HIV infections). Fortunately there is progress in some nations in achieving an all-volunteer supply and minimum screening. Thus, there are two drastically different pictures of blood safety and availability worldwide. ${ }^{97}$

Even in the developed world, availability remains a challenge. In the United States, the number in the population eligible to donate blood with all the new restrictions is 111 million, rather than the 177 million previously thought. ${ }^{98}$ Finding ways to motivate sufficient numbers of people to donate remains 


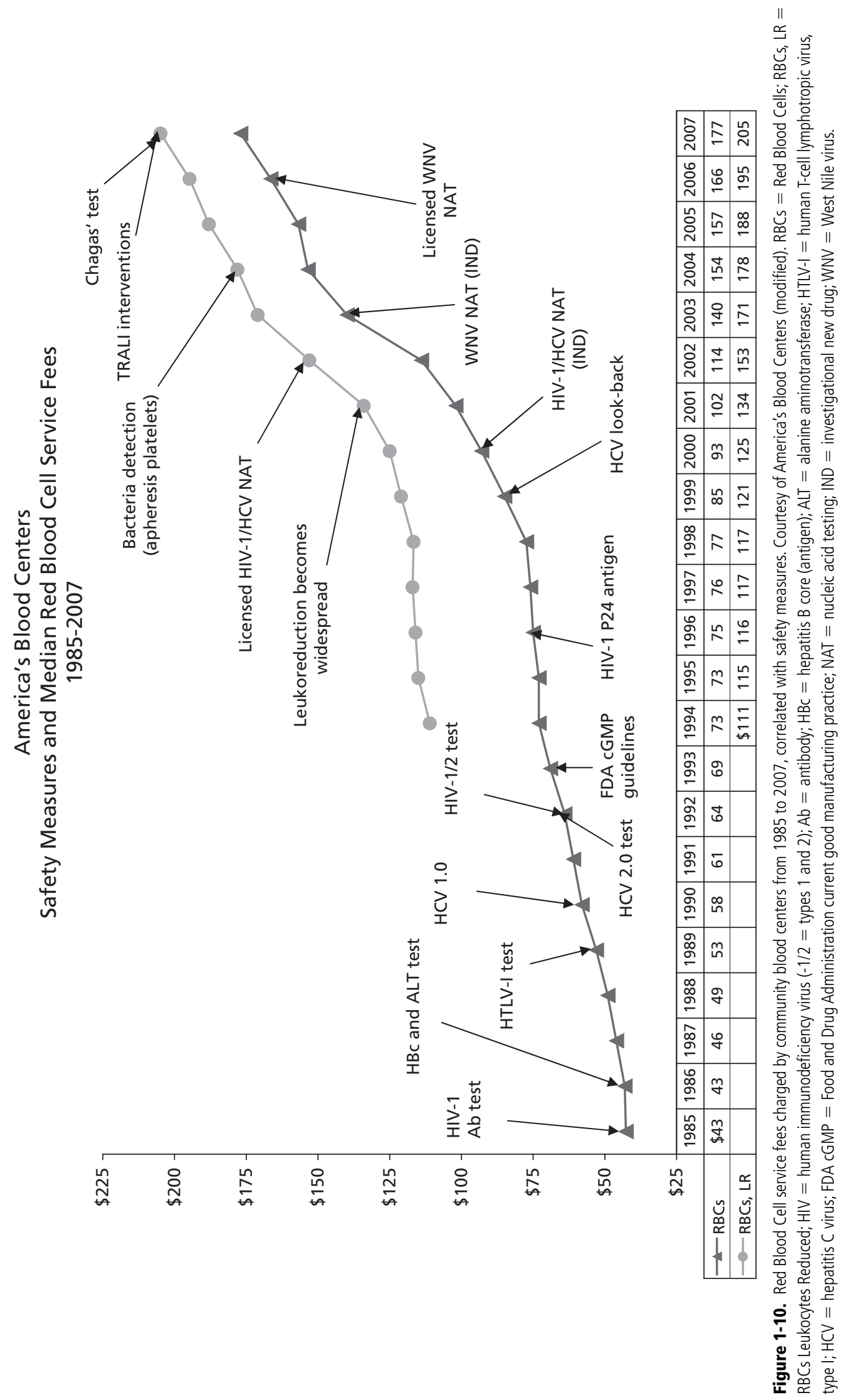


difficult. One suggestion has been to "personalize" the benefits. An example of this approach is having donors meet face-to-face with groups of recipients. Another response has been the use of cognitive interview evaluation and focus groups to define a more user-friendly questionnaire with computer-assisted techniques in many centers. ${ }^{99}$ More aggressive marketing to growing minority populations as well as continued use of various incentives seem to have increased donations in some locations. A clear need is for more group O red cells; populations of non-European ethnicity generally have an increased proportion of group O. ${ }^{100}$

Another approach to maintain adequate availability is to control usage by ensuring that blood is used appropriately. Some US blood centers have been successful in bringing their transfusion medicine expertise into the patient-care setting by providing transfusion services to hospitals. The model in Seattle, WA, has operated for decades. ${ }^{101,102}$ In the United Kingdom, liaison systems for blood centers to hospitals employing Web-based technology for supply chain management have been introduced. ${ }^{103,104}$ In Denmark, success has been reported using the Thromboelastograph (Haemoscope, Niles, IL) hemostatic system to manage coagulopathy in conjunction with treating physicians—-something also done in many US hospitals. ${ }^{105}$ Other point-of-care tests to assess the state of the coagulation system and tissue oxygenation could also result in more accurately targeted component transfusion. Transfusion medicine specialists in hospitals-whether from pathology groups, blood center staff, or other areas such as anesthesiology or hematology-are critical to the successful use of blood transfusion in patient care.

Although some advances in transfusion medicine at the end of the last millennium have been difficult to implement, such as use of hemoglobin solutions and some pathogen inactivation technologies, the field has continued to advance into new areas of stem cell biology, regenerative medicine, and cord blood banking. In addition, transfusion medicine specialists increasingly function in collaboration with surgeons, oncologists, and hematologists in treating the acutely ill patient with complex medical problems. With all the added sophistication, the optimal hemoglobin and platelet triggers and endpoints for transfusion remain unsettled. Clinicians are less likely to use oxygenation transport endpoints to determine the need for red cell transfusion but are beginning to look for other means to assess tissue oxygenation. If a patient's hemoglobin is too high (even when below normal), complications such as thromboembolism can result. Too low an endpoint exposes some patients to the risk of tissue hypoxia. The clearest trend has been away from autologous transfusion, although some medical centers seek bloodless medicine and surgery combining pharmacotherapy (mainly erythropoietin and iron), blood recovery and reinfusion, and conservative triggers and endpoints. ${ }^{94}$ More conservative triggers and endpoints for platelet transfusion are becoming accepted, but approaches to alloimmunized patients and bacterial contamination are still in question. ${ }^{106}$ Also debatable is whether transfusion, through some poorly quantifiable mechanism such as immunomodulation, confers a poorer prognosis on acutely ill patients.

From ancient times into the new millennium, blood has been a substance that fascinates mankind. Despite unresolved controversies, blood transfusion remains of critical importance in the care of sick patients throughout the world.

\section{Disclaimer}

The authors have disclosed no conflicts of interest.

\section{References}

1. Majno G. The healing hand. Cambridge, MA: Harvard University Press, 1975:330-332,402-3.

2. Garrison FH. An introduction to the history of medicine. Philadelphia: WB Saunders, 1928:17-74.

3. Ficarra BJ. Essays on historical medicine. New York: Froben Press, 1948:96.

4. Zimmerman LM, Howell KM. History of blood transfusion. Ann Med Hist 1932;4:415-33.

5. Bulfinch T. Mythology. New York: Random House, 1855:111-12.

6. Brown HM. The beginnings of intravenous medication. Ann Hist Med 1917;1:177-97.

7. Lindeboom GA. The story of a blood transfusion to a pope. J Hist Med 1954;9:455-9.

8. Maluf NSR. History of blood transfusion. J Hist Med 1954;9:59-107.

9. Wren C. An account of the rise and attempts, of a way to conveigh liquors immediately into the mass of blood. Philos Trans R Soc Lond 1665;1:128-30.

10. Hollingsworth MW. Blood transfusion by Richard Lower in 1665 . Ann Hist Med 1928;10:213-25.

11. Lower R. The success of the experiment of transfusing the blood of one animal into another. Philos Trans R Soc Lond 1666;1:352.

12. Lower R. The method observed in transfusing the blood out of one animal into another. Philos Trans R Soc Lond 1666;1:353-8.

13. Hoff EC, Hoff PM. The life and times of Richard Lower, physiologist and physician (1631-1691). Bull Hist Med 1936;4:517-35.

14. Lower R. An account of the experiment of transfusion practised upon a man in London. Philos Trans R Soc Lond 1667;2:557-9.

15. Brown H. Jean Denis and transfusion of blood, Paris, 1667-1668. Isis 1948;39:15-29.

16. Hoff HE, Guillemin R. The first experiments on transfusion in France. J Hist Med 1963;18:103-24.

17. Denis J. A letter concerning a new way of curing sundry diseases by transfusion of blood. Philos Trans R Soc Lond 1667;2:489-504.

18. Farr AD. The first human blood transfusion. Med Hist 1980;24:143-62.

19. Walton MT. The first blood transfusion: French or English? Med Hist 1974;18:360-4.

20. Denis J. An extract of a letter: Touching a late cure of an inveterate phrenisy by the transfusion of blood. Philos Trans R Soc Lond 1668;3:617-23.

21. Denis J. An extract of a printed letter: Touching the differences risen about the transfusion of blood. Philos Trans R Soc Lond 1668;3:710-15.

22. Jones HW, Mackmull G. The influence of James Blundell on the development of blood transfusion. Ann Hist Med 1928;20: 242-8.

23. Blundell J. Experiments on the transfusion of blood by the syringe. Med Chir Trans 1818;9:56-92. 
24. Transfusion and infusion. Lancet 1828;2:324-6.

25. Blundell J. Some account of a case of obstinate vomiting in which an attempt was made to prolong life by the injection of blood into the veins. Med Chir Trans 1819;10:296-311.

26. Blundell J. Observations on transfusions of blood. Lancet 1828;2:321-4.

27. Moss WL. A simple method for the indirect transfusion of blood. Am J Med Sci 1914;147:698-703.

28. Jennings CE. Transfusion: Its history, indications, and modes of application. New York: CH Goodwin, 1884:101.

29. Braxton-Hicks J. Cases of transfusion with some remarks on a new method of performing the operation. Guys Hosp Rep 1869;14:1-14.

30. Oberman HA. Early history of blood substitutes: Transfusion of milk. Transfusion 1969;9:74-7.

31. Schmidt PJ. Transfusion in America in the eighteenth and nineteenth centuries. N Engl J Med 1968;279:1319-20.

32. Bull WT. On the intra-venous injection of saline solutions as a substitute for transfusion of blood. Med Rec 1884;25:6-8.

33. Landsteiner K. Ueber Agglutinationserscheinungen normalen menschlichen Blutes. Wien Klin Wochenschr 1901;14:1132-4.

34. Dixon B. Of different bloods. Science 84 1984;5:65-7.

35. Decastello A, Sturli A. Ueber die Isoagglutinine im Serum gesunder und kranker Menschen. Munch Med Wochenschr 1902;49:1090-5.

36. Carrel A. The transplantation of organs: A preliminary communication. JAMA 1905;45:1645-6.

37. Walker LG Jr. Carrel's direct transfusion of a five day old infant. Surg Gynecol Obstet 1973;137:494-6.

38. Crile GW. The technique of direct transfusion of blood. Ann Surg 1907;46:329-32.

39. Bernheim BM. Blood transfusion: Hemorrhage and the anaemias. Philadelphia: JB Lippincott, 1917:259.

40. Ottenberg R. Reminiscences of the history of blood transfusion. J Mt Sinai Hosp 1937;4:264-71.

41. Pepper W, Nisbet V. A case of fatal hemolysis following direct transfusion of blood by arteriovenous anastomosis. JAMA 1907;49:385-9.

42. Ottenberg R. Transfusion and arterial anastomosis. Ann Surg 1908;47:486-505.

43. Ottenberg R, Kaliski DJ. Accidents in transfusion: Their prevention by preliminary blood examination: Based on an experience of 128 transfusions. JAMA 1913;61:2138-40.

44. Epstein AA, Ottenberg R. A simple method of performing serum reactions. Proc N Y Pathol Soc 1908;8:117-23.

45. Ottenberg R. Studies in isoagglutination, I: Transfusion and the question of intravascular agglutination. J Exp Med 1911;13:425-38.

46. Diamond LK. The story of our blood groups. In: Wintrobe MM, ed. Blood, pure and eloquent. New York: McGraw-Hill, 1980:658-717.

47. Levine P, Stetson RE. An unusual case of intragroup agglutination. JAMA 1939;113:126-7.

48. Landsteiner K, Wiener AS. An agglutinable factor in human blood recognized by immune sera for rhesus blood. Proc Soc Exp Biol Med 1940;43:233.

49. Unger LJ. A new method of syringe transfusion. JAMA 1915;64:582-4.

50. Hustin A. Principe d'une nouvelle methode de transfusion. J Med Bruxelles 1914;12:436.

51. Agote L. Nuevo procediemento para la transfusion del sangre. An Inst Mod Clin Med Buenos Aires 1915;2:24-30.

52. Lewisohn R. A new and greatly simplified method of blood transfusion. Med Rec 1915;87:141-2.
53. Weil R. Sodium citrate in the transfusion of blood. JAMA 1915;64:425-6

54. Rous P, Turner JR. The preservation of living red blood cells in vitro. J Exp Med 1916;23:219-48.

55. Robertson OH. Transfusion with preserved red blood cells. Br Med J 1918;1:691-5.

56. Loutit JF, Mollison PL. Advantages of a disodium-citrate-glucose mixture as a blood preservative. Br Med J 1943;2:744-5.

57. Duran-Jorda F. The Barcelona blood transfusion service. Lancet 1939;1:773-5.

58. Fantus B. The therapy of the Cook County Hospital. JAMA 1937;109:128-31.

59. Yudin SS. Transfusion of cadaver blood. JAMA 1936;106:997-9.

60. Strumia MM, McGraw JJ. The development of plasma preparations for transfusions. Ann Intern Med 1941;15:80-7.

61. Flosdorf EW, Mudd S. Procedure and apparatus for preservation in "lyophile" form of serum and other biological substances. J Immunol 1935;29:389-425.

62. Diamond LK. History of blood banking in the United States. JAMA 1965;193:40-5.

63. Walter CW, Murphy WP Jr. A closed gravity technique for the preservation of whole blood in ACD solution utilizing plastic equipment. Surg Gynecol Obstet 1952;94:687-92.

64. Gibson JG II, Sack T, Buckley ES Jr. The preservation of whole ACD blood, collected, stored and transfused in plastic equipment. Surg Gynecol Obstet 1952;95:113-19.

65. Cohn EJ. The separation of blood into fractions of therapeutic value. Ann Intern Med 1947;26:341-52.

66. Patek AJ, Taylor FHL. Hemophilia, II: Some properties of a substance obtained from normal human plasma effective in accelerating the coagulation of hemophilic blood. J Clin Invest 1937;16:113-24.

67. Pool JG, Shannon AE. Production of high-potency concentrates of antihemophilic globulin in a closed-bag system. N Engl J Med 1965;273:1443-7.

68. Lewisohn R. Blood transfusion: 50 years ago and today. Surg Gynecol Obstet 1955;101:362-8.

69. Rosenfeld RE. Early twentieth century origins of modern blood transfusion therapy. Mt Sinai J Med 1974;41:626-35.

70. Beeson PB. Jaundice occurring one to four months after transfusion of blood or plasma. JAMA 1943;121:1332-4.

71. Blumberg BS, Alter HJ, Visnich S. A "new" antigen in leukemia sera. JAMA 1965;191:541-6.

72. Feinstone SM, Kapikian AZ, Purcell RH, et al. Transfusion-associated hepatitis not due to viral hepatitis type A or B. N Engl J Med 1975;292:767-70.

73. Choo QL, Kuo G, Weiner AJ, et al. Isolation of a cDNA clone derived from a blood-borne non-A non-B viral hepatitis genome. Science 1989;244:359-62.

74. Ammann JA, Cowan MJ, Wara DW, et al. Acquired immunodeficiency in an infant: Possible transmission by means of blood products. Lancet 1983;1:956-8.

75. Curran JW, Lawrence DN, Jaffe H, et al. Acquired immunodeficiency syndrome (AIDS) associated with transfusions. N Engl J Med 1984;310:69-75.

76. Sarngadharan MG, Popovic M, Bruch L, et al. Antibodies reactive with a human T-lymphotropic retrovirus (HTLV-III) in the serum of patients with AIDS. Science 1984;224:506-8.

77. Allen JG, Sayman WA. Serum hepatitis from transfusions of blood. JAMA 1962;180:1079-85. 
78. Surgenor DM, Schnitzer SS. The nation's blood resource: A summary report. National Institutes of Health (NIH) publication no. 85-2028. Bethesda, MD: US Department of Health and Human Services, Public Health Service, NIH, 1985.

79. Surgenor DM, Wallace EL, Hao SHS, et al. Collection and transfusion of blood in the United States, 1982-1988. N Engl J Med 1990;322:1646-51.

80. Wallace EL, Surgenor DM, Hao HS, et al. Collection and transfusion of blood and blood components in the United States, 1989. Transfusion 1993;33:139-44.

81. Wallace EL, Churchill DM, Surgenor GS, et al. Collection and transfusion of blood and blood components in the United States, 1994. Transfusion 1998;38:625-36.

82. Sullivan MT, McCullough J, Schreiber GB, Wallace EL. Blood collection and transfusion in the United Stated in 1997. Transfusion 2002;42:1253-60.

83. Sullivan MT, Wallace EL. Blood collection and transfusion in the United States in 1999. Transfusion 2005;45:141-8

84. US Department of Health and Human Services. The 2007 National Blood Collection and Utilization Survey Report. Washington, DC: DHHS, 2008.

85. Essex M. Origin of AIDS. In: DeVita VT, Hellman S, Rosenberg SA, eds. AIDS: Etiology, diagnosis, treatment, and prevention, 3rd ed. Philadelphia: JB Lippincott, 1992:3-11.

86. Starr D. Blood: An epic history of medicine and commerce. New York: Alfred A Knopf, 1998;147-357.

87. Solomon JM. The evolution of the current blood banking regulatory climate. Transfusion 1994;34:272-7.

88. Schreiber GB, Busch MP, Kleinman SH, et al. The risk of transfusion-transmitted viral infection. N Engl J Med 1996;334:1685-90.

89. Busch MP, Kleinman SH. Report of the interorganizational task force on nucleic acid amplification testing of blood donors: Nucleic acid amplification testing of blood donors for transfusion-transmitted infectious diseases. Transfusion 2000;40:143-59.

90. Tabor E. The epidemiology of virus transmission by plasma derivatives: Clinical studies verifying the lack of transmission of hepatitis $\mathrm{B}$ and $\mathrm{C}$ viruses and HIV type 1. Transfusion 1999;39:1160-8.

91. Goodnough LT. The case against universal WBC reduction (and for the practice of evidence-based medicine). Transfusion 2000;40:1522-7.
92. Murphy MF. Application of bar code technology at the bedside: The Oxford experience. Transfusion 2007:47(Aug Suppl): 120S-4S.

93. Dzik, S. Radio frequency identification for prevention of bedside errors. Transfusion 2007; 47(Aug Suppl):125S-9S.

94. Klein HG, Spahn DR, Carson JL. Red blood cell transfusion in clinical practice. Lancet 2007;370:415-26

95. MacPherson J, Mahoney CB, Katz L, et al. Contribution of blood to hospital revenue in the United States. Transfusion 2007;47(Aug Suppl):114S-16S.

96. Hoffman A, Gomhotz A, Theusinger OM, Spahn DR. Estimating the cost of blood: Past, present and future directions. Best Pract Res Clin Anaethesiol 2007;21:271-89.

97. Improving blood safety worldwide (editorial). The Lancet 2007;370:361.

98. Riley W, Schwei M, McCullough J. The United States potential blood donor pool: Estimating the prevalence of donor exclusion factors on the pool of potential donors. Transfusion 2007;47:1180-8.

99. Fridey JL, Townsend MJ, Kessler D, Gregory K. A question of clarity: Redesigning the American Association of Blood Banks blood donor history questionnaire-A chronology and methodology for donor screening. Transfus Med Rev 2007;21:181-204.

100. Simon TL. Where have all the donors gone? A personal reflection on the crisis in America's volunteer blood program. Transfusion 2003;43:273-9.

101. Yazer M. The Pittsburgh centralized transfusion model: Less is more. Transfusion 2007;47(Aug Suppl):164S-9S.

102. Gottschall JL. Blood centers and hospitals: A model for clinical interactions and services. Transfusion 2007;47(Aug Suppl):172S-6S.

103. Allen T. Blood center and hospital relationships in England and North Wales: Their impact on the declining demand for red blood cells? Transfusion 2007;47(Aug Suppl):158S-63S.

104. Chapman J. Unlocking the essentials of effective blood inventory management. Transfusion 2007:47(Aug Suppl):190S-6S.

105. Johansson PI. The blood bank: From provider to partner in treatment of massively bleeding patients. Transfusion 2007:47(Aug Suppl):176S-81S.

106. Stroncek DF, Rebulla P. Platelet transfusions. Lancet 2007;370:427-38. 